\title{
Sakarya Meydan Muharebesi Savaş Alanındaki Erozyona Uğramış Siper Hatlarının Yer Radarı (GPR) Yöntemi ile Belirlenmesi
}

\author{
Sinan KOŞAROĞLU1,2 (D), Züheyr KAMACI2 ${ }^{\circledR}$, Özcan BEKTAŞ*3(D) \\ 1,3Sivas Cumhuriyet Üniversitesi, Mühendislik Fakültesi, Jeofizik Mühendisliği Bölümü, 58140, Sivas, Türkiye \\ 2Süleyman Demirel Üniversitesi, Mühendislik Fakültesi, Jeofizik Mühendisliği Bölümü, 32260, Isparta, Türkiye
}

(Alınış / Received: 26.03.2021, Kabul / Accepted: 25.05.2021, Online Yayınlanma / Published Online: 15.08.2021)

\section{Anahtar Kelimeler}

Sakarya Meydan Muharebesi, Siper,

Yer Radarı (GPR),

Sedimantasyon,

Uydu Görüntüsü,
Özet: Sakarya Meydan Muharebesi, hem Türk Devletinin tarihi hem de Dünyanın en uzun süreli ve en büyük meydan savaşı olması yönünden oldukça önem taşımaktadır. Bu savaşta Sakarya Nehri doğusunda 1921 yılında Türk Kuvvetleri ile Yunan Kuvvetleri savașmıșlar ve her iki taraftan da çok fazla insan hayatını kaybetmiştir. Doğa Koruma ve Milli Parklar Genel Müdürlüğü'nün 2015 yllında başlattığı kapsamlı çalışmalarla Şehit Defin Alanları ile Siper hatlarının konumları belirlenmektedir. Dönemin şartları göz önüne alındığında ve Bölgesel Jeomorfolojik yapıya uygun olarak siper hatları olușturulmuștur. Bu hatlar imkansızlıklar ve zaman kısalığından dolayı bir çok bölgede 1-1.30 metre derinliğinde hazırlanmıș boy çukuru olabilecek alanlardır. Bu çalışmada savaş esnasında kullanılan ancak savaştan sonra sedimantasyon etkisi ile kaybolmaya yüz tutmuş siper hatlarının yer radarı (GPR) yöntemi ile belirlenmesi amaçlanmıştır. Yüksek frekanslı ve Geniş Band (80-950 MHz) GPR yöntemi ile uydu görüntülerinde takip edilebilen ancak yüzeyde izi kaybolmuş siper hattı boyunca 2 ve 3 boyutlu ölçümler alınarak siper hatlarının devamlılığı ve sedimantasyon sınırları başarılı bir șekilde tespit edilmiştir.

\section{Determination of Erosion Trench Lines in the Battlefield of the Sakarya Pitched Battle by Ground Radar (GPR) Method}

\section{Keywords}

Sakarya Field Battle,

Entrenchment, Ground Penetrating Radar (GPR),

Sedimentation, Satellite Image

\begin{abstract}
The Sakarya Field Battle is very important in terms of both the history of the Turkish State and the world's longest and largest pitched battle. In this war, Turkish Forces and Greek Forces fought east of the Sakarya River in 1921 and many people died from both sides. The locations of Martyr Burial Grounds and Trench lines are determined with the comprehensive studies initiated by the General Directorate of Nature Conservation and National Parks in 2015. Considering the conditions of the period and in accordance with the Regional Geomorphological structure, trench lines were created. These lines are areas that can be prepared height pit at 1-1.30 meters depth in many regions due to impossibilities and short time. In this study, it is aimed to determine the trench lines that were used during the war but disappeared with the effect of sedimentation after the war by ground radar (GPR) method. The continuity of the trench lines and the sedimentation boundaries were successfully determined by taking $2-3$ dimensional measurements along the trench line, which can be tracked in satellite images with the high frequency and Wide Band (80-950 MHz) GPR method, but lost traces on the surface.
\end{abstract}

\section{Giris}

Sakarya Meydan Muharebesi Viyana kapılarında başlayan geri çekilmenin son noktası olmuştur. Kuvayi Milliye birliklerinin göstermiş oldukları bölgesel çaptaki direnişler, Kütahya-Eskişehir Savaşlarından

\footnotetext{
*ilgili yazar: obektas@cumhuriyet.edu.tr
}

itibaren düzenli ordu ile düşmana karşı konulması ile sonuçlanmıştır [1]. Her ne kadar düzenli ordu sistemine geçilse de Türk tarafında askeri bakımdan eksiklikler oldukça fazla idi. Bu eksikliklerin başında asker ve mühimmat sayısındaki azlık yanında ordunun geri hizmetleri de yetersiz kalmıștır. Sakarya 
Meydan Muharebesinde askeri bakımdan göze çarpan en temel eksiklik, savaş alanına ait haritaların sadece kroki derecesinde olmasıdır. Çanakkale Savaşlarında Osmanlı devleti askeri açıdan bütün unsurları ile savaşı kabul etmiştir ancak Sakarya Meydan Muharebesinde Türk Ordusu düzenli ordu sistemini yeni kurulma sürecindeydi.

Sakarya Meydan Muharebesi 22 gün 22 gece süren bir savaştır. Gerek süresi gerekse savaş alanı ile Dünyanın en uzun süreli ve en büyük savaş alanına sahiptir. Bu bölge Sakarya nehri boyunca Polatlı ve Haymana ilçeleri sınırlarını kapsamaktadır (Şekil 1). Savaşın geçtiği alan yaklaşık olarak 100 km uzunluğa ve 30 km derinliğe sahiptir. $\mathrm{Bu}$ oranda büyük bir alanda savaşmak sadece askeri sayıdan üstünlük ile sağlanamamıştır. Özellikle Türk tarafı alışılagelmiş askeri taktiklerin yanında Alan savunması yaparak Savașta üstünlük sağlamıştır. Bu savunma stratejisinin temelinde askerin savaşı en uygun yerde siper hatları oluşturarak savunma savaşı yapması esasına dayanmaktadır [1].

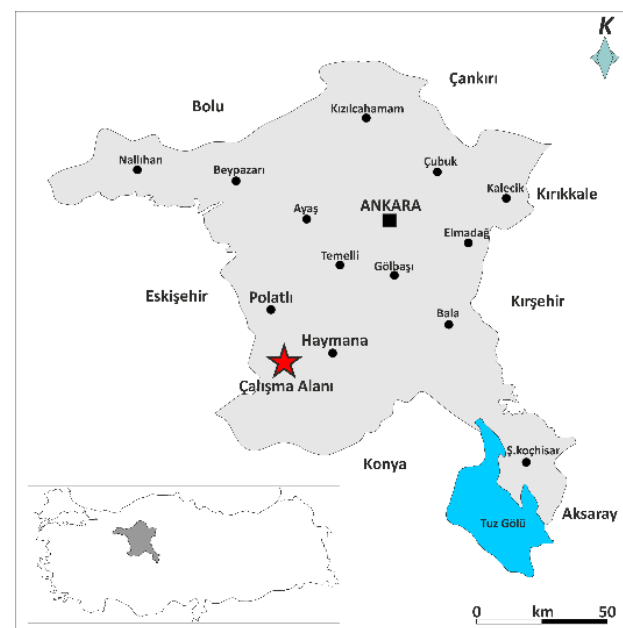

Şekil 1. Sakarya Meydan Muharebesinin yapıldığı alana ait Yer Bulduru haritası

Ancak askeri açıdan üstün olan Yunan kuvvetleri cephede birçok bölgede Türk tarafını çekilmeye zorlamıștır. Fakat özellikle Çal Dağı'ndaki muharebeler esnasında Mustafa Kemal Paşa tarafından yayınlanan bir ordu emri ile birliklere 'Hattı Müdafaa Yoktur, Sath-ı müdafaa vardır, 0 satıh bütün vatandır' emri uyarınca birlikler savaşa en uygun arazi kesimde yeniden savunma hatları oluşturarak savaşa devam etmişlerdir. Dünya tarihinde daha önce eşine rastlanmamış olan bu savunma stratejisi neticesinde Yunan kuvvetleri yenilgi kabul ederek Eskişehir-Afyon hattına çekilmek zorunda kalmışlardır [1].

Siper, taarruz eden düşman askerlerini esas savunma hattına yaklaşmadan kayıp verdirerek durdurmayı amaçlayan ve belirli bir düzende kazılmış çukur hatları olarak tanımlanabilir. Bunun yanında düşman tarafından ağır ve hafif silahlarla açılacak ateş sonucu askerlerin korunmalarını ve savaş esnasında hayatlarını sürdürmelerini sağlamaktadır. Siper çeşitleri genellikle Savaş meydanlarında düşman askerinin geliş yönlerini görecek şekilde uygun olan toprak zeminler kazılarak hazırlanmaktadır. Ancak toprak yapısının uygun olmadığı kayalık zeminlerde ise taşların belirli hatlar boyunca dizilerek geçici duvarlar örülmesi ve düşman ateşinden korunaklı olması için oluşturulan hatlardır. Savaş alanları, gerek savaş esnasında gerek savaş sonrasında askerler tarafından birçok farklı amaç için kullanılmaktadır[2]. Askerler savaş esnasında korudukları alanları savunmak için bu hatları kullanırken savaşta ölen askerler için ise mezar alanları oluşturulmuştur. Savaş sonrasında bu bölgelerde yapılan çalışmalar ağırlıklı olarak mezar alanlarının yerlerinin belirlenmesi amacıyla yapılmıștır [3,4]. Sakarya Meydan Muharebesinde kullanılmış olan siperlerin büyük bir kısmı çukur siperler şeklinde hazırlanmıştır. Siper hatlarının tasarımındaki diğer bir etmende düz bir hat oluşturmak yerine aralarda zikzak şeklinde küçük bağlantı noktalarının olmasıdır. Bu alanlar düşman tarafından ateşlenen top mermisi veya siper hattının içerisine atılan el bombaları gibi şarapnel ve basınç etkilerini en aza indirilmesi amaçlanmıștır. Ayrıca bu noktalar ile düşman askerlerinin sipere girdiği noktalarda zikzak şeklinde bir yapı olduğu için hattın diğer kesimindeki askerlerin savaşa devam etmesini amaçlamaktadır [2]. Savaş döneminde yapılmış olan bu hatlar savaștan sonraki dönemlerde bozulmaya uğrayarak kaybolma tehlikesi ile karşı karşıya kalmaktadır. Ayrıca bu alanlarda tarımsal faaliyetler ve diğer etkenlerden dolayı kazılmış olan çukurların iç kısımları sedimanter malzeme ile dolarak siper hatlarının yeryüzünde takip edilmeleri güçleşmiştir. $\mathrm{Bu}$ durum özellikle Sakarya Meydan Muharebesinin yaşandığı alanda fazlası ile gözlemlenmektedir. Sakarya nehrinin bir yay çizdiği Polatlı ve Haymana ilçesi sınırlarında bulunan bölge tarımsal faaliyetlerin yapıldığı bir bölgedir. Devamlılıkları arazide tespit edilemeyen siper hatlarının belirlenmesi için alternatif çalışmaların yapılmasına ihtiyaç duyulmuştur. $\mathrm{Bu}$ çalışmaların ise en iyi sonuçlar verdiği yöntemler sığ jeofizik yöntemler olarak gösterilebilir. Arkeolojik alanlarda uygulanan jeofizik yöntemlerin yanında farklı uygulamalar ile yapılan çalışmalar yeni yaklaşımların ortaya çıkmasını sağlamaktadır. Özellikle jeomorfolojik sediman yapısının insan etkisiyle değiştirilmesi sı̆̆ jeofizik yöntemlerde tespit edilebilmektedir $[5,6,7]$. Birçok farklı jeofizik yöntem kullanılmakla beraber jeomorfolojik değişimlerin en net belirlendiği yöntem olarak yer radarı yöntemi kullanılabilir. Yüksek frekans kullanan bu yöntemde kazılarak yapısı değiștirilmiş katmanlar belirlenebilmektedir. Robin vd. 2020 [8] Güneybatı Fransa'da Truc-Vert kıyı kesimindeki sahil morfolojisindeki değişimleri GPR yöntemi ile araştırmaları sonucunda doğal süreçlerle (erozyon, rüzgar, sedimantasyon) ve insan etmeni ile sediman birikimlerini araştırmışlardır. Arşiv kayıtları ve güncel GPR verileri ile sediman istifin dönemlerine göre sınırlarını net bir şekilde ortaya çıkarmışlardır. 
Pollard ve Blanks, 2010 [9], Birinci Dünya Savaşı sırasında İngiliz kuvvetlerinin Almanlara karşı kullanmış oldukları savunma hatlarını ve savaș malzemelerini Jeofizik yöntemler kullanarak tespit etmişlerdir.

\section{Materyal ve Metot}

Yer radarı yöntemi sığ yüzey araştırmaları için sıklıkla kullanılan jeofizik yöntemlerden bir tanesidir. Bu yöntemde kullanılan frekanslar çalışma derinliğine göre farklılıklar göstermektedir. Anten frekanslarının belirlenmesinde araștırılması planlanan hedefin derinliği, boyutu ve içinde bulunduğu jeolojik birimin özellikleri belirleyici unsurları oluşturmaktadır. Bu yöntem esas olarak verici anten (Tx) vasitası ile üretilen belirli bir frekanstaki EM dalganın yer içerisine gönderilmesi ve yeraltında farklı ortamlardan gelen yansiyan-kırılan sinyallerin kaydedilmesi prensibine dayanmaktadır. $\mathrm{Bu}$ yöntemde gönderilen orijinal sinyal ile yeraltında farklı ortamlardan dolayı değișime uğramıș sinyallerin karşılaştırılması esastır. Yer altında farklı fiziksel ve kimyasal özelliklere sahip ortamlar GPR sinyallerinin hızları üzerinde belirleyici unsurdur. Eğer sinyalin seyahat süresi belirlenebilir ise ortamın ortalama EM dalga hızı kolaylıkla hesaplanarak yansımaya neden olan hedef yapının derinliği hassas bir şekil de tespit edilebilir [4]. Uygulamada kullanılan GPR sinyallerinin seyahat süresi nanosaniye $\left(10^{-9}\right)$ olarak kullanılmaktadır. Ölçüm yapılacak alan içerisinde amaca göre 2 boyutlu dikey kesitler olușturulur. Eğer alan daha detaylı araştırılmak istenirse bu hatlara paralel diğer 2 boyutlu hatlar birleștirilerek alanda 3 boyutlu yer altı yapısı ortaya çıkarılabilmektedir. Mezar araştırmalarında da kullanılan temel prensiplerden bir tanesi bu durumdur. Ayrıca insan kalıntılarından meydana çıkan farklılıklar da sığ jeofizik ölçümlerde anomaliye sebep olmaktadır [3].

Yer radarı prensip olarak belirli frekansta yayın yapan alıcı ve verici ünitelerinden oluşmaktadır. $\mathrm{Bu}$ çalışmada, Geniş Band (Widerange) olarak tanımlanan yeni nesil Yer radarı anten sistemi kullanılmıștır. Bu sistemde anten frekanslarının aralıkları geniş tutularak tek bir frekans kümesi yerine farklı frekans kümeleri kullanarak ölçümler yapılmaktadır. Yeni nesil olarak tasarlanan bu anten sistemlerindeki en temel amaç farklı frekans gruplarını tek bir radargram üzerinde birleştirerek yansımaların daha net elde edilmesidir. Ayrica bu anten sistemlerinde frekans dalga boyundan kaynaklı olan anten kör zonunu en aza indirilmesi amaçlanmaktadır. Düşey ölçekte tek bir merkezi frekans grubu kullanmak yerine geniş band frekans aralığı kullanmak özellikle düşey ölçekte çözünürlüğü arttırmaktadır. Bu frekans kümelerinde Yüksek frekans değerlerinin kullanıldığı ortalama frekans değeri yaklaşık olarak $625 \mathrm{MHz}$ dir. Düşük Frekans değerlerinin kullanıldığı ortalama frekans değeri ise yaklaşılk olarak $180 \mathrm{MHz}$ dir (Șekil 2).
Frekans kümesinin tek bir değer yerine geniş bir aralığa sahip olmasının bazı dezavantajlarında bulunmaktadır. Bu sistemlerde her ne kadar korumalı (Shielded) antenler kullanılsa da geniș bir spektruma sahip olan EM dalgalarından dolayı ölçümlerde gürültü/sinyal oranı düşebilmektedir. $\mathrm{Bu}$ anten sistemlerinde karşlaşlan bu sorun genel olarak BandPass filtresi ile giderilmesi amaçlanmaktadır. $\mathrm{Bu}$ durum ise tek band frekans değerine sahip antenlerden elde edilen verilere uygulanan temel veri işlem adımları yanında karmaşık veri işlem adımlarını uygulamayı zorunlu kılmaktadır. Yüksek Frekans band aralığına sahip veri setine uygulanan veri işlem adımları ve parametre değerleri Tablo 1.'de verilmiştir.

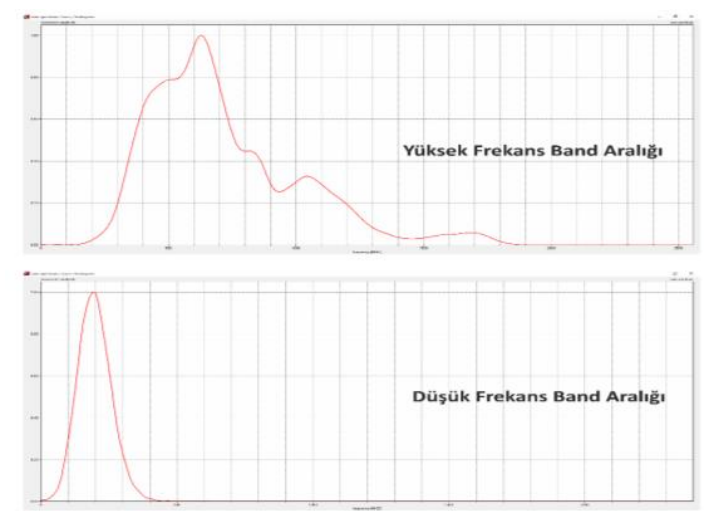

Şekil 2. Geniş Band (WideRange) Yer radarı anteninde kullanılan Temel Anten Frekansları

Tablo 1. Ham yer radarı verilerine uygulanan veri işlem adımları ve kullanılan parametre değerleri

\begin{tabular}{ll}
\hline Veri İşlem Parametreleri & Kullanılan Değerler \\
\hline Anten Temel Frekansı & $625 \mathrm{MHz}$ HDR (80-950 MHz) \\
Başlangıç zaman kesme & $6.0 \mathrm{~ns}$ \\
Zaman kesme & $80 \mathrm{~ns}$ \\
Dewow & $8 / 1 \mathrm{~ns}$ \\
Enerji Gecikmesi & 0.512 \\
Ortalama Çıkarma & $51 / 1$ \\
Band pass filtre & $250 / 500 / 750 / 1000 \mathrm{MHz}$ \\
Migrasyon & $7 / 0.1 \mathrm{~ns}$ \\
Envelope & $45 / 1$ \\
\hline
\end{tabular}

\section{Bulgular}

Sakarya Meydan Muharebesinde Türk tarafının kullanmış olduğu siper hatları temelde 4 ana savunma hattı şeklindedir [1]. Savaştan sonra savaş alanlarında yapılan araștırmalarda Askeri arşiv belgelerinden yararlanarak şehit mezar defin alanlarını ve siperlerin konumlarını eski haritaları kullanarak belirlemişlerdir [3]. Ancak bu savaş alanındaki çalışmalarda arşiv kayıtlarından savaştan sonraki yapılan incelemeler için referans alınması oldukça güçtür. $\mathrm{Bu}$ nedenle alanda yapılan araştırmalarda farklı pek çok değişkenin göz önünde bulundurulması gerekmektedir. Savaş alanında yapılan çalışmalarda arşiv belgeleri, arazi gözlemleri, görgü tanıklarının ifadeleri, uydu gözlemleri ve jeofizik çalışmalar 
beraber kullanılmıştır [1]. Çalışma alanı Türk savunma sisteminin birinci ana hattı üzerinde bulunan ve Kavakköy yerleșiminin hemen güneyinde yer almaktadır. Özellikle askeri açıdan bir düzen içerisinde yapılmış olan siper hatlarının sistematiğini anlamak için siper hattı boyunca elde edilen koordinat bilgileri Sayısal yükseklik verileri üzerine işlenmiştir. Sayısal yükseklik verileri baz alınırken çalışma yapılan alanın 1/25.000 harita indeksine göre sinırları alınmıştır. Jeofizik çalışmanın yapıldığı alan J28B4 paftasında yer almaktadır. Bu harita üzerinde 1. ve 2. Savunma hatlarının konumları harita üzerinde işaretlenmiștir (Şekil 3).

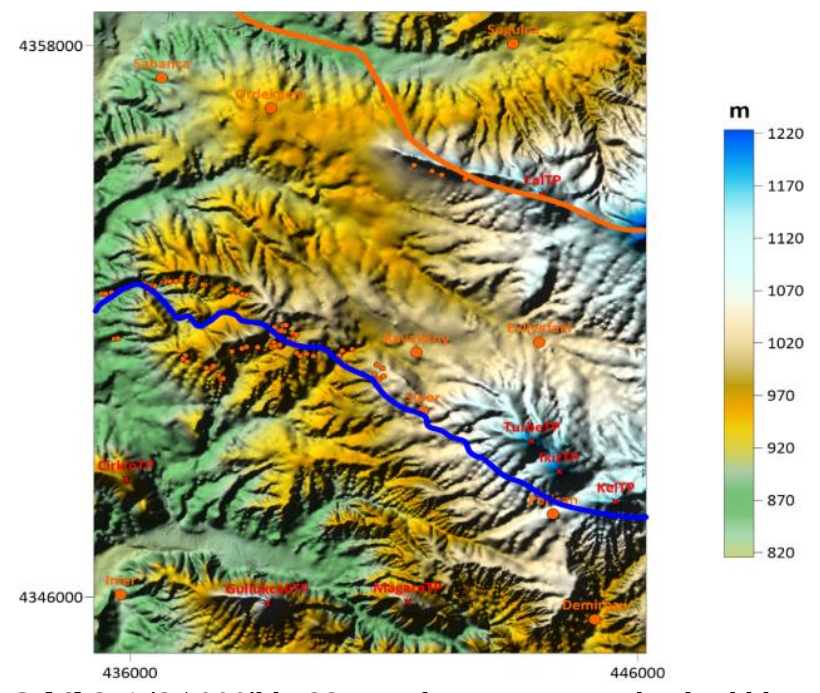

Şekil 3. 1/25.000’lık J28B4 paftasına ait sayısal yükseklik haritası

Belirlenen ana siper hatları uydu görüntüleri kullanılarak da devamlılıkları takip edilebilmektedir (Şekil 4 ve Şekil 5a, b, c ve 5d). Uydu görüntüleri incelendiğinde siperlerin genellikle alana hakim tepeler üzerinde konumlandırıldıkları gözlemlenmiștir. $\mathrm{Bu}$ bölümdeki siper hattının uzunluğu yaklaşık olarak $10 \mathrm{~km}$ civarındadır. Bölgenin hakim jeolojik yapısı Paleojen yaşlı kırıntılılar ve karbonatlı birimlerden oluşmaktadır.

Siper hatlarının oluşturulmasında temel etkenin hakim tepeler boyunca düşmanın taarruz istikametine uygun şekilde yapıldığı anlaşılmaktadır (Şekil 6). Elde edilen sonuçlarda siperlerin genellikle bölgeye hakim tepe sıraları üzerinde yerleştikleri gözlemlenmiștir. Özellikle Türk tarafının ilk savunma hattı bu şekilde oluşturulmuştur.

Siper hatları üzerinde yapılan Jeofizik çalışmalarda yüksek frekans band aralığına sahip Yer radarı veri setleri değerlendirilmeye tabii tutulmuştur. Yapılan ölçümlerde ölçüm aralıklarının bir metre olarak belirlenmiştir. İnceleme alanında $40 \times 25$ metrelik (1.600 $\left.\mathrm{m}^{2}\right)$ bir alanda detaylı yer radarı ölçümleri yapılmıştır (Şekil 7). Alınmış olan yer radarı ölçümlerinde hem 2 boyutlu hem de 3 boyutlu değerlendirmeler yapılmıştır. Çalışma alanında 1 metre profil aralıkları ile alınmış olan ölçümler
Reflexw V6.0 programı ile değerlendirilmiştir [10]. Siper hatları uydu görüntüleri üzerinden takip edilmesi mümkün olsa da arazide erozyondan ötürü siper hatlarını takip edilmesi oldukça güçtür. Savaş esnasında açllan siperler malzeme yetersizliği sebebi ile gerektiği kadar desteklenememiştir. Siper hatlarını desteklemek için eksik olan korugan, tel örgü, ahşap gibi malzemeler olmadığı için siperler genellikle dayanıksızdır. Yunan topçusunun yoğun ve güçlü ateşi de siperleri daha savaş esnasında oldukça fazla ölçüde tahrip etmiştir [1]. Bu sebeple günümüze ulaşabilen birçok alanda siper hatları kaybolma noktasına gelmiștir (Şekil 8 ve Şekil 9). Ayrıca bölgedeki tarımsal faaliyetlerde bazı hatların bozularak kaybolmasına sebep olmuştur.

Çalışma alanında alınmış olan veri setlerinin jeolojik değerlendirilmesi ve anomali olduğu düşünülen kesimler Şekil 10a ve b 'da verilmiştir. Çalışma alanında toplanan 25 adet profiller değerlendirilmiş ve elde edilen sonuçlardan 5 tanesi değerlendirilmiştir (Şekil 10a). Söz konusu incelemede Migrasyon ve Envelope filtreleri uygulanmış veri setleri kullanılmıştır. Migrasyon uygulanmış veriye yapılan "envelope" veri işlem aşaması ile genlikleri max-min olan bölgelerin ortalama değerleri hesaplanmıştır. Özellikle bu işlem adımı ile farklı Jeolojik seviyelerin devamlılığı başarılı bir şekilde takip edilebilmektedir (Şekil 10b). Yapılan değerlendirmede inceleme alanına ait jeolojik tabaka sınırları net bir şekilde belirlenmiştir. Özellikle siper hattına ait olan bölümdeki düşük genlikli yansımalar dikkat çekicidir. Bu kesimde gözlemlenen anomali ile alanda savaş esnasında açıldığı düşünülen siper çukurunun zaman içerisinde sedimanter istif tarafından tekrar doldurulduğu net bir şekilde gözlemlenmektedir (Şekil 11). Bunun dışında kalan kesimlerde ise jeolojik istifte insan kaynaklı bir değișim gözlemlenmemiștir. Bu kesimdeki siper çukurunun alt derinliğinin yaklaşık olarak 1.30 metre derinlik seviyesine kadar net bir șekilde gözlemlenmektedir. Alanda yapılan ölçümlerin devamlılıklarının araştırılması için alınan ölçümler bilgisayar ortamında birleștirilerek 3 boyutlu blok diyagram olarak değerlendirilmiştir (Şekil 12). Yapılan 3 boyutlu değerlendirme sonucunda anomali alanının bir hat boyunca devamlılığı olduğu gözlemlenmiştir.

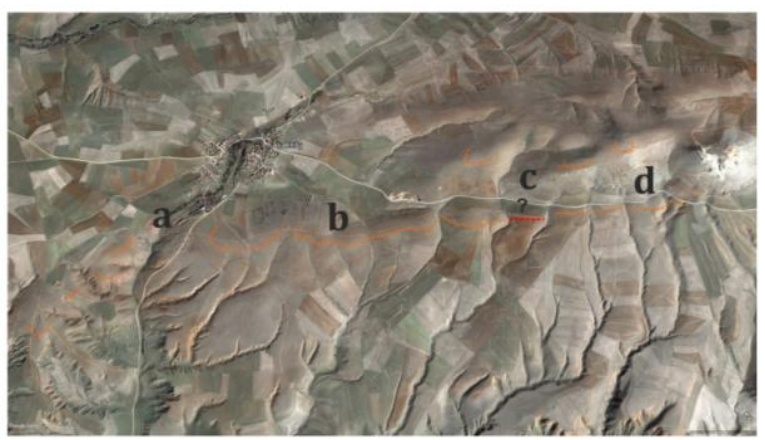

Şekil 4. Kavakköy güneyinde bulunan 1. Ana savunma hattına ait uydu görüntüsü 


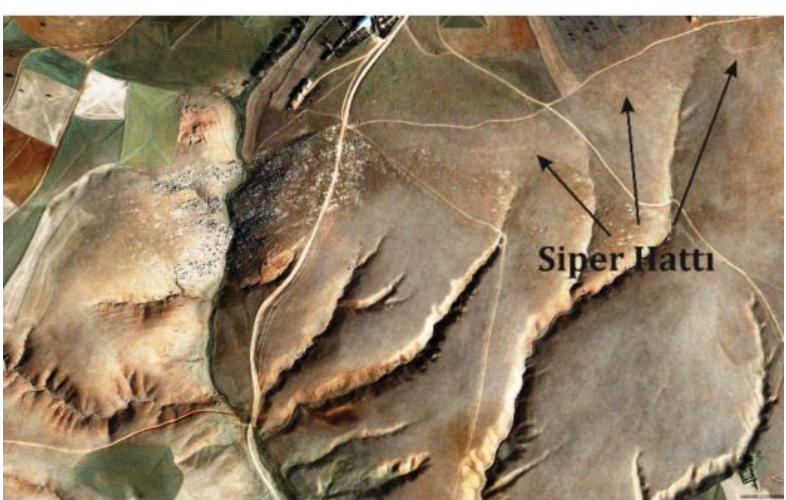

Şekil 5a. Kavakköy güneyinde bulunan 1. Ana savunma hattına ait uydu görüntüsü

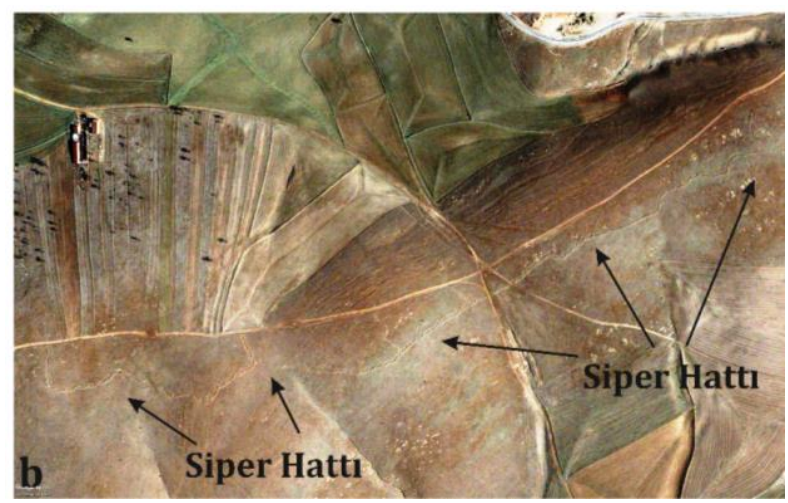

Şekil 5b. Kavakköy güneyinde bulunan 1. Ana savunma hattına ait uydu görüntüsü

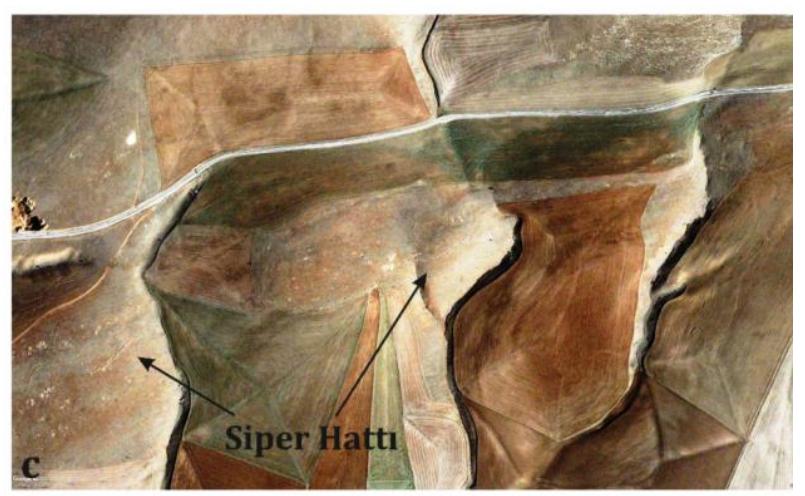

Şekil 5c. Kavakköy güneyinde bulunan 1. Ana savunma hattına ait uydu görüntüsü

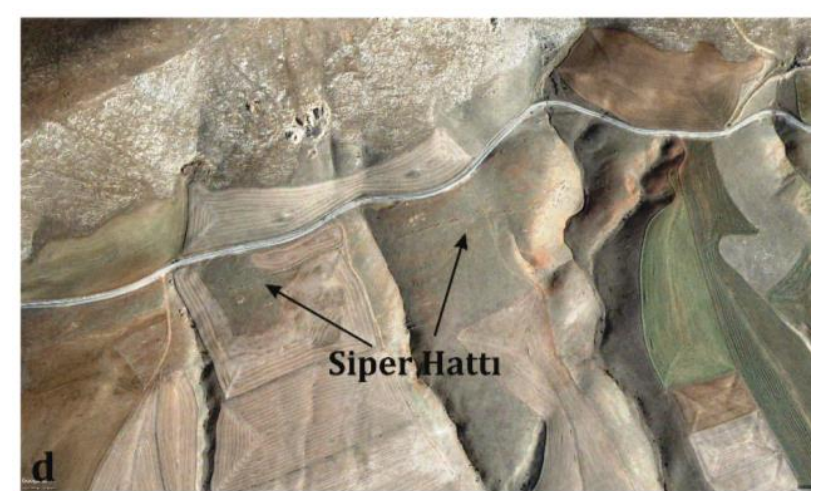

Şekil 5d. Kavakköy güneyinde bulunan 1. Ana savunma hattına ait uydu görüntüsü

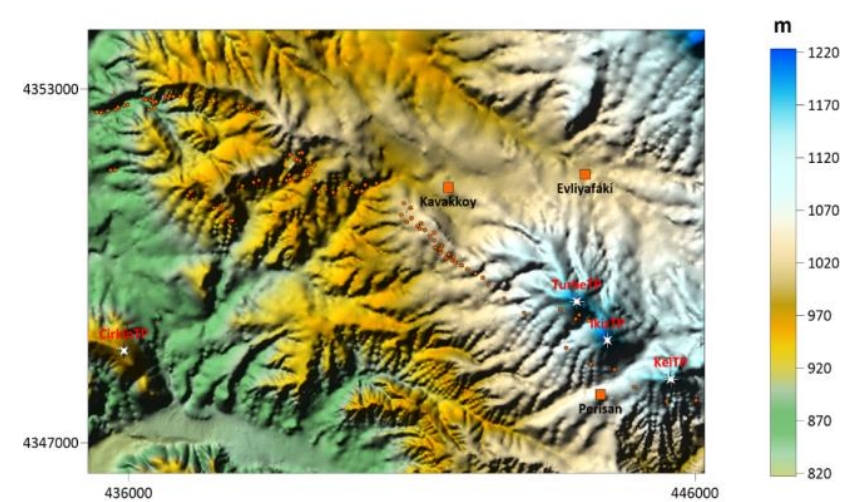

Şekil 6. 1/25.000'lık J28B4 paftasına ait yükseklik haritası ve siper hatlarının konumları

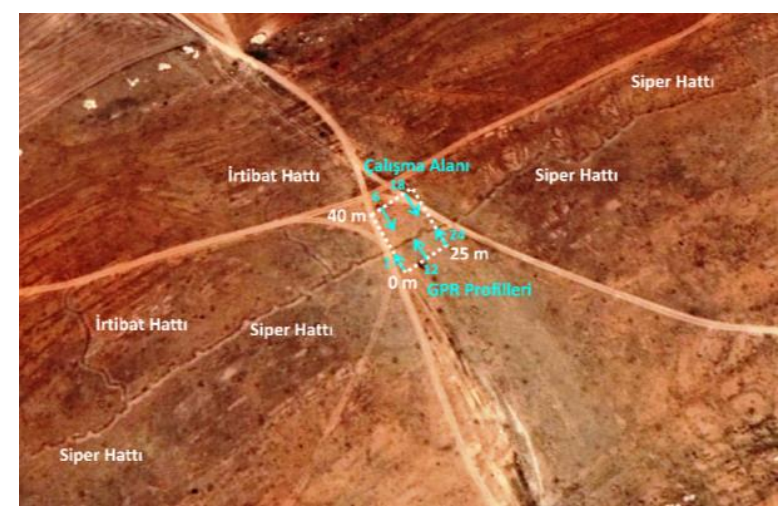

Şekil 7. Yer radarı ölçümü yapılan alan ve siper hatlarının devamlılıkları

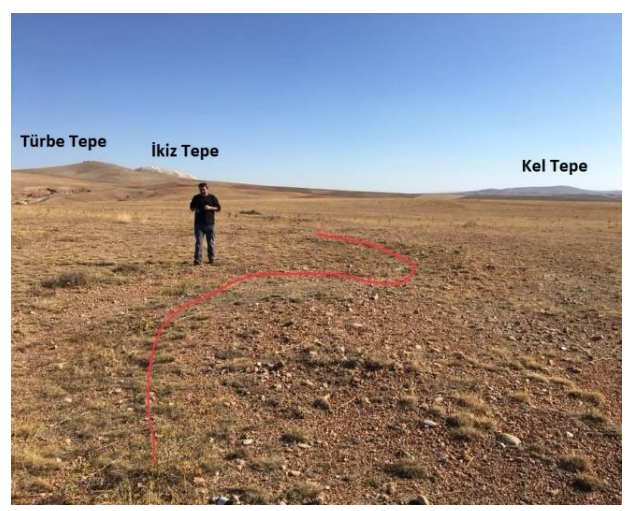

Şekil 8. Kavakköy güneyindeki ölçüm alanına ait siper hattının görüntüsü [1]

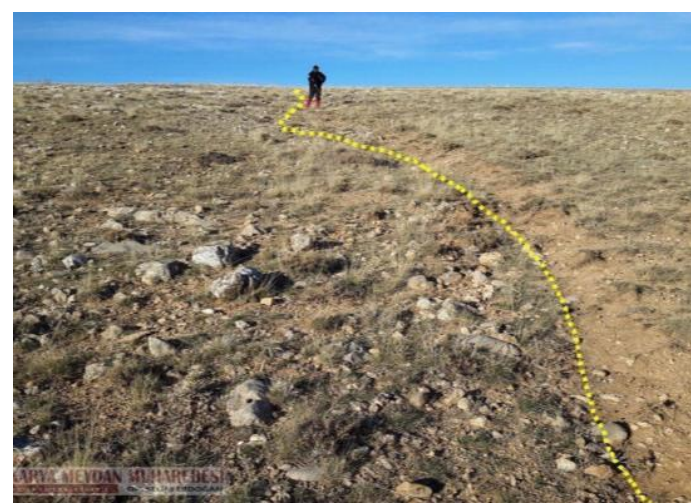

Şekil 9. Kavakköy güneyindeki siper hatlarının görüntüsü [1]. 

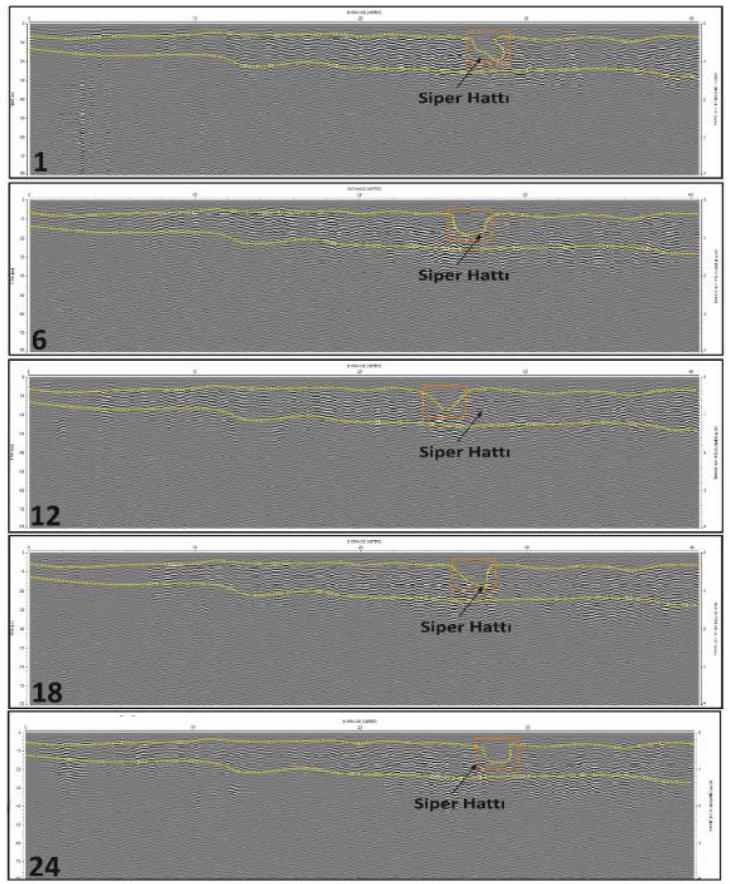

Şekil 10a. Yorumlanmış 2 boyutlu Yer radarı kesitleri (Yer radarı kesitleri üzerindeki rakamlar profil numaralarını göstermektedir)
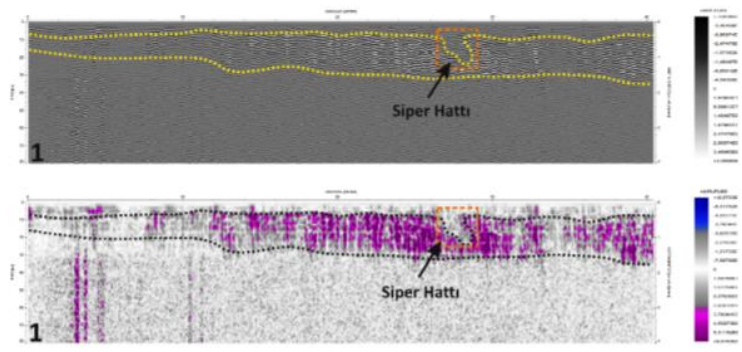

Şekil 10b. Yorumlanmış ve envelope dönüşümü yapılmış 2 boyutlu Yer radarı kesitleri

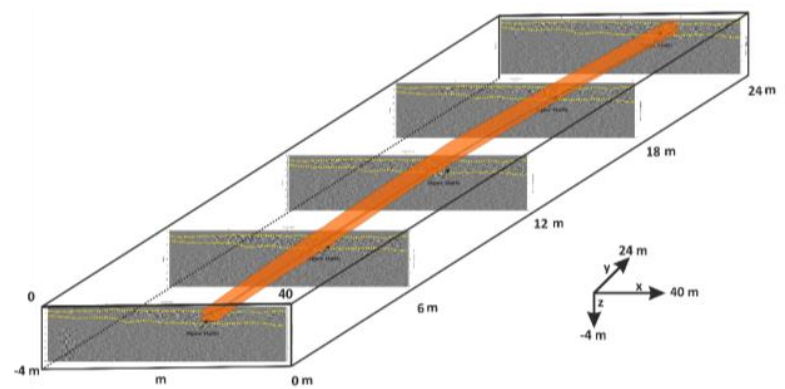

Şekil 11. Değerlendirmesi yapılan radar ölçümleri ve siper hattının radargram kesitleri üzerindeki devamlılıkları

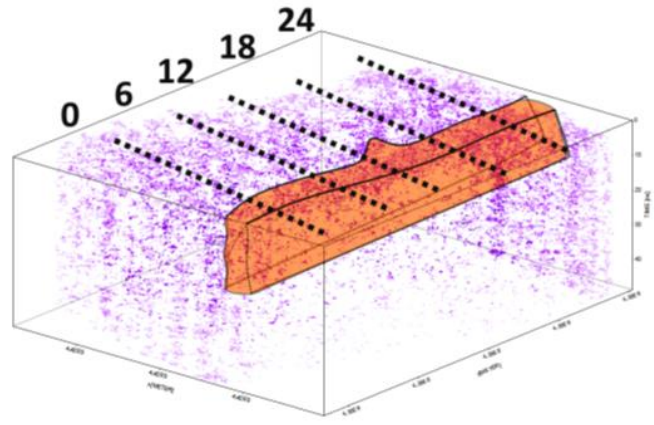

Şekil 12. 3 boyutlu blok diyagram

\section{Tartışma ve Sonuç}

Savaş alanlarında sığ Jeofizik yöntemler kullanılarak savaş sonrasındaki kalıntılar araştırılmaktadır. $\mathrm{Bu}$ çalışmalar genellikle patlamış-patlamamış mühimmatlar, savaș malzemeleri ve savaș esnasında ölen askerlerin defin yerlerinin belirlenmesi amaçları ile yapılmaktadır. Ancak bu çalışmada farklı olarak üzerinden 100 yll gibi bir süre geçmesine rağmen uydu görüntülerinde devamlılıkları tespit edilebilen siper hatlarının derinlik yapıları araștırılmıștır. Üzerinden geçen zaman içerisinde yüzeyde kaybolmuş bu hatlar Yer radarı yöntemi kullanılarak detaylı bir şekilde araştırılmıștır ve farklı zamanlara ait Jeolojik istifin sınırları detaylı bir şekilde ortaya çıkarılmıştır. Söz konusu savaş alanı günümüzde tarımsal faaliyetlerin oldukça fazla yapıldığı bir bölgedir. Gerek zaman gerekse tarımsal faaliyetler ve diğer etmenler savaş alanındaki kalıntıları olumsuz yönde etkilemektedir. Zaman içerisinde rüzgar ve yağmur kaynaklı getirilmiș olan malzemelerle dolarak yüzeydeki izleri kaybolmuștur (Șekil 13). Yer radarı yöntemi ile zamanla yüzeydeki izleri kaybolmuş siper hatları başarılı bir şekilde tespit edilebilmiştir.

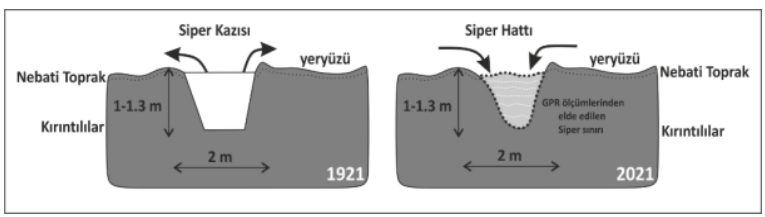

Şekil 13. Erozyon mekanizmasına ait Jeomorfolojik model

\section{Teșekkür}

Bu çalışma, Süleyman Demirel Üniversitesi Bilimsel Araştırmalar Projeleri Koordinasyon Birimi tarafından FDK-2019-7316 nolu Doktora Tez Projesi kapsamında desteklenmiștir. Bu araștırma, Tarım ve Orman Bakanlığı, Doğa Koruma Milli Parklar Genel Müdürlüğü adına gerçekleştirilmiş olup, yayınlanabilmesi için gerekli izinler alınmıștır. Çalışmanın tüm evrelerinde destek ve yardımlarını esirgemeyen DKMP Genel Müdürlüğü Sakarya Meydan Muharebesi Tarihi Milli Park Müdürlügü̈ne teșekkür ederiz.

\section{Etik Beyanı/Declaration of Ethical Code}

$\mathrm{Bu}$ çalışmada, "Yükseköğretim Kurumları Bilimsel Araştırma ve Yayın Etiği Yönergesi" kapsaminda uyulması gerekli tüm kurallara uyulduğunu, bahsi geçen yönergenin "Bilimsel Araștırma ve Yayın Etiğine Aykırı Eylemler" başliğı altında belirtilen eylemlerden hiçbirinin gerçekleștirilmediğini taahhüt ederiz.

\section{Kaynakça}

Erdoğan, S. 2020. Sakarya Türk Bitti Demeden Bitmez. Kronik yayınları. 
[2] Duman, S. 2019. Anadolu Topraklarında Siper Hatlarl.

https://www.akademiktarihtr.com/anadoluda siperhatlari/ (Erişim Tarihi:18.07.2020).

[3] Büyüksaraç, A., Yalçıner, C. C., Ekinci, Y. L., Demirci, A., Yücel, M. A. 2014. Geophysical investigations at Agadere Cemetery, Gallipoli Peninsular, NW Turkey. Australian Journal of Forensic Sciences, 46(1), 111-123.

[4] Yalçıner, C. C., Kurban, Y. C. 2018. Determination of Grave Locations with High Resolution Ground Penetrating Radar (GPR) in war Cemeteries: Sample study of Biga (Çanakkale) War, Journal of Science and Technology, 8(2), 85-89.

[5] Smedt, P. D., Saey, T., Lehouck, A., Stichelbaut, B., Meerschman, E., Islam, M. M., Vijver, E. V. De., Meirvenne, M. V. 2013.Exploring the potential of multi-receiver EMI survey for geoarchaeological prospection: A 90 ha dataset, Geoderma, 199, 30-36.

[6] Conyers, L. B., Ernenwein, E. G., Grealy, M., Lowe, K. M. 2008. Electromagnetic conductivity mapping for site prediction in meandering river floodplains, Archaeological Prospection, 15, 8191.

[7] Simpson, D., Van Meirvenne, M., Lück, E., Rühlmann, J., Saey, T., Bourgeois, J. 2010. Sensitivity of multi-coil frequency domain electromagnetic induction sensors to map soil magnetic susceptibility. European Journal of Soil Science, 61, 469-478.

[8] Robin, N., Billy, J., Castelle, B., Hesp, P., Lerma, A. N., Laporte-Fauret, Q., Marieu, V., Rosebery, D., Bujan, S., Destribats, B., Michalet, R. 2020. 150 years of foredune initiation and evolution driven by human and natural processes, Geomorphology, 374, 107516.

[9] Pollard, T., and Banks, I. 2010. Now the Wars are Over: The Past, Present and Future of Scottish Battlefields, Int. J. Histor. Archaeol., (14), 414441.

[10] Sandmeier, K.J., 2003. Reflexw 4.3 Software Manuel Book Sandmeier Software, Zipser Strasse 1, D-76227 Karlsruhe, Germany. 